\title{
Structure and Functions of Lactoferrin as Ingredient in Infant Formulas
}

\author{
Esmat Aly ${ }^{1,2}$, Gaspar $\operatorname{Ros}^{1} \&$ Carmen Frontela ${ }^{1}$ \\ ${ }^{1}$ Department of Food Science and Nutrition, Faculty of Veterinary Sciences, Regional Campus of International \\ Excellence "Campus Mare Nostrum". University of Murcia, Spain \\ ${ }^{2}$ Food Technology Research Institute, Agricultural Research Center, Giza, Egypt \\ Correspondence: Esmat Aly, Department of Food Science and Nutrition, Faculty of Veterinary, Regional \\ Campus of International Excellence "Campus Mare Nostrum". University of Murcia, Spain, Campus \\ Universitario, Universidad de Murcia, 30100 Espinardo, Murcia, Spain. Tel: 34-868-88-4798. E-mail: \\ esmat_rayan_2010@yahoo.com, esmat.aly@um.es
}

Received: March 21, 2013 Accepted: June 15, 2013 Online Published: June 21, 2013

doi:10.5539/jfr.v2n4p25 URL: http://dx.doi.org/jfr.v2n4p25

\begin{abstract}
It has been widely accepted that breastfeeding is the best food for newborns. Mother's milk provides all the nutritive elements for normal growth and development of infants being considered the first functional food in life. Because it contains a variety of compounds playing a key role in the adequate feeding of newborns, such as oligosaccharides, probiotics, polyunsaturated fatty acids and lactoferrin. Lactoferrin from human milk has been demonstrated to be responsible for the resistance of newborns to infections and also has many biological activities that are essential for an adequate health of infants. Recently, there is also a growing interest in the potential use of lactoferrin for the improvement of bone health and cancer prevention. Milk substitutes and infant formulas play a vital role in infant nutrition when the breastfeeding is not available. The design of infant formula is modeled on the composition of human milk and the current trend in the infant formulas manufacturing is looking to provide not only nutritional compounds but also similar functional effects than human milk.
\end{abstract}

Keywords: lactoferrin, iron absorption, infant formula, antibacterial, immunomodulation

\section{Introduction}

It is considered according to the American Academy of Pediatrics (AAP, 2012) that the breastfeeding is the preferred choice of feeding for all infants and recommended that the exclusive breastfeeding for about the first 6 months is very important, followed by continued breastfeeding with introducing of some of the complementary foods when breast milk alone is no longer sufficient to meet the nutritional requirements of infants. It is worthy to note that breastfeeding continue for 1 year or longer as desired by mother and infant. So breastfeeding is undoubtedly the best form of nutrition for newborns and young infants and its advantage go far beyond nutritional and anti-infective benefits (Mathew, 2004). The importance of breastfeeding is not only providing essential nutrients to infants, but it has many healthy benefits for both children and their mothers (Kramer \& Kakuma, 2002). The benefits of breastfeeding have been well described in the medical literature and including providing optimal nutrition, preventing common childhood illnesses and improving child spacing (Abiona et al., 2006).

The breast feeding for at least 6 months can decrease worldwide mortality diarrhea, respiratory illness, and other infectious disease by up to $55 \%$ (Chantry, Howard, \& Auinger, 2006), and this due to the components of breast milk that are considered major contributors to decrease morbidity rates in breastfed infants (Newburg, 2000). One of these major active components is lactoferrin which has many healthy effects on the newborns such as the antimicrobial effects which add to the protective factor of breast milk (Story \& Parish, 2008).

Breast milk contains an important and multiple immunological and anti-infective factors (Chirico, Marzoll, Cortinovis, Fonte, \& Gasparino, 2008). They include, among many others, proteins with antimicrobial properties such as secretory IgA, lysozyme, and lactoferrin; lactoferrin provides immune-modulating properties in addition to its better-known anti-infective properties. Oligosaccharides in breast milk inhibit bacterial adhesion, further protecting against pathogens, and white blood cells provide passive immune protection. Nucleotides and 
cytokines also assist with T-cell maturation and immune system modulation, evidenced by, e.g., the more robust immune response that breast-fed infants exhibit after vaccination. Breast milk also promotes healthful gastrointestinal microbiota (Zivkovic, German, Lebrilla, \& Mills, 2011), and can actively stimulate development of the newborn's host defenses to provide continued mucosal protection after breast feeding is terminated. Several components of breast milk such as growth factors, interleukin 10 and also lactoferrin can reduce the inflammatory response to stimuli in the newborn intestine (Petit, 2008; Walker, 2010). Human milk lactoferrin has been demonstrated to increase the resistance of newborns to infections and also has many biological activities that are essential for an adequate health of infants. Recently, lactoferrin has taken more attention in regarding with some healthy activities like its role in the improvement of bone health, cancer prevention and its role as transcripttion factor. It is able to enter a cell and to activate the transcription of specific DNA sequences and this lactoferrin-DNA interaction is reported to be responsible for antiviral role (Adlerova, Bartoskova, \& Faldyna, 2008).

With this background, the aim of this review is to provide an overview of the state of the art in research regarding the functional role of lactoferrin added to infant formulas such as, in maintaining immune homeostasis, nutrient intestinal absorption, prebiotic effect, bone health improvement or chronic diseases prevention, providing better knowledge on the use of lactoferrin as ingredient in infant formulas.

\section{Lactoferrin: Structure and Properties}

Breast milk is rich in a lot of biologically active components that are beneficial for the health of newborns (Ella, Ahmed, Umoh, Ogala, \& Balogun, 2009). Lactoferrin is one of these active components isolated firstly from cow's milk and after from human milk (Losnedahl, Wang, Aslam, Zou, \& Hurley, 1998). It is the second most abundant protein in human milk and belongs to the transferrin family (Connely, 2001).

Lactoferrin is the major iron-binding protein in milk from several species, such as in human (10-15\%) (Baró, Jiménez, Martinez-Férez, \& Boza, 2001) acting as a first line defense agent against infections in the body (Coonely, 2001). It is found at the highest levels in human colostrum $(7 \mathrm{~g} / \mathrm{L})$ and at a lower level $(2-4 \mathrm{~g} / \mathrm{L})$ in mature human milk (Sacrino, 2007), meanwhile the amount of lactoferrin is lower in cow's milk $(0.01 \mathrm{~g} / \mathrm{L}$ ) and generally its content varies depending on the species (Wakabayashi, Yamauchi, \& Lonnerdal, 2006). Structurally, Bovine lactoferrin (bLF) is an iron-binding glycoprotein of approximately $77 \mathrm{kDa}$ and consists of a single polypeptide chain of about 700 amino acids. Meanwhile, human lactoferrin is a glycoprotein with a molecular weight of about $80 \mathrm{kDa}$, which shows high affinity for iron. Lactoferrin is a polypeptide chain that contains of 703 amino acids distributed as follows: from amino acid 1 to 332 (lobe N) and from 344 to 703 (lobe C) with a three-turn connecting helix (residues 333-343) and that is sensitive to proteolytic attack. Each lobe contains an iron-binding site $\left(\mathrm{Fe}^{+3}\right)$ with a high affinity, and a glycan. $\mathrm{N}$ and $\mathrm{C}$ lobes have very similar conformations but show slight differences in their affinity for iron (Kaim \& Schwederski, 1994).

The sequence homology between human and bLF is about 70\% and the 3-D structure of human and bovine lactoferrin are very similar but not identical (Steijns \& van Hooijdonk, 2000). It is well known that iron is the main cation bound by lactoferrin (Lonnerdal \& Iyer, 1995) and there are three forms of lactoferrin according on its iron saturation: apolactoferrin (iron free), monoferric form (one ferric iron), and hololactoferrin (binds two $\mathrm{Fe}^{3+}$ ions) (Jameson, Anderson, Norriss, Thomas, \& Baker, 1998). The three dimensional structure of diferric human lactoferrin is shown in Figure 1.

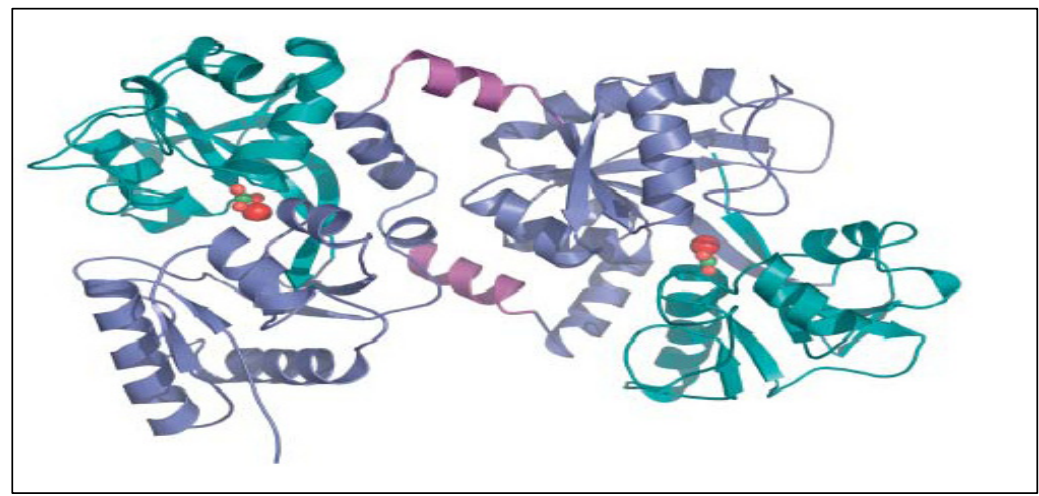

Figure1. The three dimensional structure of diferric human lactoferrin. The two ferric ions are in red (Baker, \& Baker, 2005) 
Lactoferrin has a greater affinity to bound iron and retains this metal over a wide $\mathrm{pH}$ range and it begins to release the metal at $\mathrm{pH} 4$ being, at $\mathrm{pH} 2$, the release complete, leading to formation the Apo-form (Stowell, Rado, Funk, \& Tweedie, 1991). Also, it has a greater resistance to proteolysis (Gonzales-Chavez, Arevalo-Gallegos, \& Rascon-Cruz, 2009), especially the Hololactoferrin form (Baró et al., 2001).

Lactoferrin was originally found to be a stable protein (Kuwata et al., 2001) and is only partly digested in newborn alimentary tract and may be absorbed as intact lactoferrin from the infant gut (Chatterton, Rasmussen, Heegaard, Sorensen, \& Petersen, 2004; Artym, \& Zimecki, 2005). The incomplete development of the digestive system of infants (Britton, \& Koldovsky, 1987) who lesser than 6 months lead to its presence in infant feces where it exhibits as a small percentage (1-6\%) of HoloLactoferrin. On the other hand, in the adults where the gastrointestinal tract reach to the maturity status, a decrease in the gastric $\mathrm{pH}$ values and an increase in enzymatic secretion are observed thereby enhancing proteolysis (Davidson \& Lonnerdal, 1987).

Some of the functional roles exhibited by lactoferrin are iron-dependent, meanwhile there are others reported to be non-dependent of iron (Farnaud \& Evans, 2003). The iron-related functions are caused by the competition for iron ions between the protein and receptors of bacterial membranes. Although the function roles of lactoferrin that are non-dependent with iron binding properties are known to depend mainly on the structural region of amino acid residues 20-37 of the protein, the specific mechanisms still remain unclear (Farnaud \& Evans, 2003; Babina, Kanyshkova, Buneva \& Nevinsky, 2004).

\section{Functional Roles of Lactoferrin and Its Mode of Action}

\subsection{Lactoferrin as Iron-Binding Protein}

Iron is a pivotal and essential trace element for the maintenance of the human health due to its obligate role in a number of the physiological processes (Sharp \& Srai, 2007). Iron has to be absorbed from food and in the diet, is present in two forms which are non-heme iron (which found in cereals, vegetables, pulses, beans, fruits as simple iron oxides or complex iron chelates) and heme iron (which found in meat and meat products). Non-heme iron is predominant in all diets forming some 90-95\% (Darshan \& Anderson, 2007) while heme-iron forms 5-10\% of total daily iron intake, respectively. However, the heme-iron is the most bioavailable source of iron (20-30\%) while the non-heme iron is less bioavailable source of iron amounting of $1-10 \%$ of the dietary load (Hallberg, Brune, \& Rossander, 1989).

In human milk, the iron content is low 0.2-0.4 mg/L (Domellof, Lonnerdal, Abrams, \& Hernell, 2002) and is mainly bound to lactoferrin (20-45\%; Chierici, \& Vigi, 1994); while in cow milk it is mainly bound to casein (24\%) (Renner, Scchaafsma, \& Scott, 1989), which correlates well with the finding of Makino and Nishimura (1992), indicating that $95 \%$ of the lactoferrin of milk is in the monoferric and/or apolactoferrin form. This difference in the distribution of iron in milk from human and cow is associated with the reported differences in iron bioavailability from milk of the different species (Lonnerdal, 1989). Also it might be explained by the high level of lactoferrin present in human milk. Another possible explanation may be found in the high content of lactose and ascorbate in human milk (Cashman, 2002).

Lactoferrin plays a key role in iron homeostasis in the newborn (Sacrino, 2007). Moreover, higher concentration of lactoferrin in human milk than bovine milk raised the hypothesis that it might promote iron absorption in breast-fed infants compared with formulas-fed infants (Vorland, 1999). Also, the discovery of lactoferrin receptors in the enterocytes of various species and its high affinity for lactoferrin support this hypothesis. These lactoferrin receptors show species and molecular specificities depending of the animal species and this would explain the high bioavailability of iron from human milk, as only human lactoferrin releases iron to the enterocyte by this mechanism (Gonzalez-Chavez et al., 2009). Subsequent studies have shown how these receptors mediate the uptake of lactoferrin-bound iron in intestinal Caco-2 cell culture. In this study it was used two types of specific lactoferrin receptor, one is the purified native lactoferrin (nlfR) and the other is the recombinant lactoferrin (rlfR), and both nlfR and rlfR have the same biochemical properties. Finally, it was reported that are a unique receptor-mediated mechanism for iron uptake by the newborn (Suzuki, Shin, \& Lonnerdal, 2001).

Lactoferrin-iron complex is taken up by the enterocyte, probably by endocytosis, and then release its iron at intracellular level through lactoferrin degradation (Sanchez, Calvo, \& Brock, 1996). Iron seems to be released within the cell where it is quickly complexed by another protein, probably ferritin, and then apolactoferrin form comes back again to mucosa surface to start a new transport process (Sigel \& Sigel, 1998). In this process it was indicated that lactoferrin receptors which located at the plasma membrane of Caco- 2 cell play a main role in lactoferrin uptake through clathrin-mediated endocytosis (Jiang, Lopez, Kelleher, \& Lönnerdal, 2011). 
However, it has been reported that the ingestion of lactoferrin from a non-human source involved different pathways of iron absorption with different efficiency compared with lactoferrin of human origin (Jovani et al., 2001). Although it is technically feasible to add bovine lactoferrin or transgenic human transferrin to infant formulas, bovine lactoferrin does not bind consistently to human lactoferrin receptors and has not been shown to increase iron absorption. Moreover, the efficacy and safety of adding human lactoferrin to infant formulas has not been adequately evaluated.

In this regard, it must be noted that different studies report that the supplementation with human or bovine lactoferrin in rat's trials did not affect on iron absorption (Fairweather-Tait, Wright, \& Piper, 1986). Also infant formulas supplemented with bovine lactoferrin do not enhance iron absorption because that bovine lactoferrin is not recognized by human lactoferrin receptors (Jovani et al., 2001). Similar results obtained by Svoboda, Drábek and Ficek (2005), showed that iron from bovine lactoferrin could not be utilized by piglets because of the degree of species specificity and the replacement of part of iron dose by iron from iron-saturated lactoferrin had negative effect on piglets iron status. In this regards, it also must be noted that in another study operated by Ward, Mendoza-Meneses, Cunningham and Conneely (2003) by using a knockout mice model which has disrupted lactoferrin gene by gene targeting techniques, it was reported that lactoferrin is not required for intestinal iron uptake in the infant, indicating that the use of lactoferrin from different sources could not be the best foods-enrichment way for improving the iron absorption in humans.

\subsection{Lactoferrin as Antibacterial Agent}

Lactoferrin has strong antimicrobial activity against wide spectrum of microorganisms such as bacteria, fungi, yeasts and viruses (Drago, 2006). The antibacterial activity of lactoferrin in vitro and in vivo has been documented in the past, for Gram-negative bacteria and Gram-positive bacteria and some acid-alcohol resistant bacteria (Garcia-Montoya, Cendon, Arevalo-Gallegos, \& Rascon-Cruz, 2012). Initially it was considered that an iron-binding property is the major mechanism for its antibacterial action. Now it is well known that iron-independent mechanisms are also responsible for the antibacterial action of lactoferrin such as direct interaction with bacteria leading to membrane destabilization, modulation of bacteria motility, aggregation or endocytosis into host cells, inhibition of adherence and biofilm formation (Harvard \& Hancock, 2009). In another words, the antibacterial activity of lactoferrin is mostly due to two mechanisms. The first is the iron chelation which makes the nutrient unavailable for using by the microorganism thereby creating a bacteriostatic effect. The other mechanism is the direct interaction between lactoferrin (the positive amino acids) and the bacterial surfaces (anionic molecules) causing cell breakdown (bactericidal effect) (Gonzalo-Chavez et al., 2009).

Although there are some bacteria in response to iron-limited media has the ability to produce and secrete low molecular weight high affinity chelators which named siderfores (Yu \& Schryvers, 2002). These compounds have a higher affinity for iron chelation than lactoferrin, and then the iron-siderfores complex is taken up into bacteria by siderfores-specific receptors (Farnaud \& Evans, 2003). Also other bacteria can produce specific lactoferrin receptors that can stimulate iron removal from the protein (Yu \& Schryvers, 2002).

Lactoferrin also exerts its antimicrobial action not just in the form of the intact molecule but the monoferric lobes and active peptides of lactoferrin also have a role in the host defense against microbial disease (Lizzi, Carnicelli, Clarkson, Di Giulio, \& Oratore, 2009). These functional peptides are produced from lactoferrin by the action of proteolytic enzymes which are present in the gastrointestinal tract (Sinha, Kaushik, Kaur, Sharma, \& Singh, 2013).

Lactoferricin, multifunctional cationic peptides, is one of these peptides that are generated by the enzymatic treatment of lactoferrin and has a greater antibacterial activity than the native lactoferrin. There are two forms of lactoferricin: human and bovine lactoferricin. Lactoferricin B consists of 25 amino acids while lactoferricin $\mathrm{H}$ is a 47-amino acid peptide. Lactoferricin B is more effective as antibacterial agent than the other peptide (Bellamy, Takase, Wakabayashi, Kawase, \& Tomita, 1992). The antibacterial activity of this peptide was attributed to its action of releasing lipopolysaccharide from bacterial strains and, hence, disruption of cytoplasmic membrane permeability after cell binding (Kang, Lee, Kim, \& Hahm, 1996), and both lactoferricin (B and H) are derived from the N-terminal region of the N-lobe (Bellamy et al., 1992).

Although lactoferrin has antibacterial activity for a wide spectrum of microorganisms, it is considered a growth promoter for other organisms and acts as a bifidogenic factor for the growth of bifidobacteria (Kim, Rahman, kumura, \& Shimazaki, 2005). According to Coppa, Zampini, Galeazzi, and Gabrielli (2006) human lactoferrin supports the predominance of beneficial bacteria which require low concentrations of iron for growth, such as Lactobacillus and Bifidobacterium of the infant intestinal microflora. Although this mechanism of action is not 
fully understand, many studies suggest that the growth stimulatory activity of lactoferrin may be related to the presence of lactoferrin-binding proteins on the surface of the bacterial membrane (Kim et al., 2004).

\subsection{Lactoferrin as Cancer Preventive Agent}

The use of lactoferrin in clinical studies as a cancer preventing milk protein is a promising field of research (Tsuda, Sekine, Fujita, \& Ligo, 2002). Many studies have described that lactoferrin has anti-carcinogenic properties in several in vivo and in vitro studies and has been reported to inhibit several types of cancer (Wang et al., 2000; Matsuda et al., 2006; Giuffre, Barresi, Skliros, Barresi, \& Tuccari, 2007; Pan, Rowney, Guo, \& Hobman, 2007).

Different in vivo studies showed that oral administration of bovine lactoferrin to rodents significantly reduces chemically induced tumorigenesis in different organs (breast, esophagus, tongue, lung, liver, colon, and bladder) and inhibits angiogenesis (Tsuda et al., 2002; Iigo et al., 2009). This find could indicate that unlike to the other reported beneficial effects of lactoferrin on health, the anticarcinogenic effect seems not be highly dependent of the animal species.

There are many possible mechanisms that have been suggested by many researchers to explain the role of lactoferrin in cancer prevention. One possible mechanism is the inhibition of angiogenesis and in this regard, it was reported that bovine lactoferrin decreased vascular endothelial growth factor (VEGF)-mediated angiogenesis in rats (Norrby, Mattsby-Baltzer, Innocenti, \& Tuneberg, 2001; Tsuda et al., 2010). Another mechanism is the induction of apoptosis and the elimination of damaged cells from the body. Orally administration of lactoferrin leads to inhibition of tumorgenesis and enhances the expression of a member of tumor necrosis factor receptor family, Fas expression, which is suggested to stimulate the apoptosis and suppress the colon carcinogenesis (Fujita, Matsuda, Sekine, Ligo, \& Tsuda, 2004).

\subsection{Lactoferrin as Bone Health Enhancement Agent}

Bone is a metabolically active organ that shows a growth controlled by many hormones and growth factors (Stransky \& Rysava, 2009). Bone is continually remodelled by the complex coupling of the two actions of the bone forming cells, osteoblasts, and the bone resorbing cells, osteoclasts (Mundy, 1999). The imbalance between the activities of osteoblast and osteoclast cells lead to many bone diseases such as osteoporosis which is the most common bone disease and a major cause of the morbidity and health expenditure in aging populations (Cornish \& Naot, 2010). However, the risk of osteoporosis can be reduced or prevented by adequate nutrition and lifestyle. The prevention should start in infancy and childhood, when bone formation is intensive and achievement of optimal peak bone mass is a necessary requirement for keeping optimal bone density in the older age (Stransky \& Rysava, 2009). In this context, and adequate nutrition during infancy plays an essential role in the health bone being key nutrients for bone growth, proteins, vitamin $\mathrm{D}$ and $\mathrm{C}$, minerals such as $\mathrm{Ca}, \mathrm{P}$ and also $\mathrm{Mg}$ (Heaney at al., 2000; Whiting et al., 2004).

Nowadays, there is a growing attention in the potential use of lactoferrin for the improvement of bone health. In bone, lactoferrin functions as a growth factor, at physiological concentrations induces osteoblasts growth and activity, meanwhile inhibits osteoclast development and thus, promoting the bone growth (Cornish \& Naot, 2010). Also Lorget et al. (2002) demonstrated that bovine lactoferrin is able to inhibit in vitro osteoclast-mediated bone resorption in a rabbit mixed bone cell culture. As well as Cornish (2004) reported that bovine or human lactoferrin at low physiological concentrations, exerted a dual effect characterized by an important inhibition of osteoclast differentiation with a simulating effect on osteoblast proliferation. It is also possible that lactoferrin regulates bone homeostasis through the modulation of cytokine production. The ingestion of bovine lactoferrin can have an indirect effect on bone through its capacity to regulate the immune system by decreasing tumor necrosis factor (TNF) production (Blais, Malet, Mikogami, Martin-Rouas, \& Tomé, 2009). Similar results reported that oral administration of bovine lactoferrin led to suppress TNF $\alpha$ production and increase interleukin-10 (IL-10) production in adjuvant-stimulated arthritic rats (Hayashida et al., 2004). Thus, dietary supplementation of bovine lactoferrin to ovariectomized mice would decrease TNF production, which subsequently normalized the elevated osteoclastogenesis observed in estrogen-deficient situations (Blais et al., 2009).

In another study, the positive effects of lactoferrin in bone have been demonstrated in vitro; where lactoferrin was found to induce osteoblast proliferation, survival and differentiation meanwhile inhibits osteoclast formation. In vivo, lactoferrin given as a dietary supplement to rat and mice, has been demonstrated to has a protective effect against bone loss associated with estrogen deficiency (Naot, Grey, Reid, \& Cornish, 2005). In this context, lactoferrin could be considered a promising therapeutic tool in prevention of osteoporosis and repair the damage tissue in bones. Thus, lactoferrin not only inhibits bone resorption but also has the capacity to activate the bone 
formation as contrary with the most of the currently used medications for osteoporosis prevention (Wang et al., 2013). Lactoferrin acts to increase the bone mass (Figure 2.).

During inflammation, lactoferrin may play a role in counter-balancing the catabolic effects on the skeleton from some of the mediators of the inflammatory response. Also lactoferrin plays an important immunodulatory function (Baveye, Elass, Mazurier, Spik, \& Lergand, 1999) and this lead to decrease in the secretion of a number of osteolytic cytokines. Therefore, its direct effects on the activity and development of bone cells appear to be complemented by these cytokine-mediated effects (Naot et al., 2005)

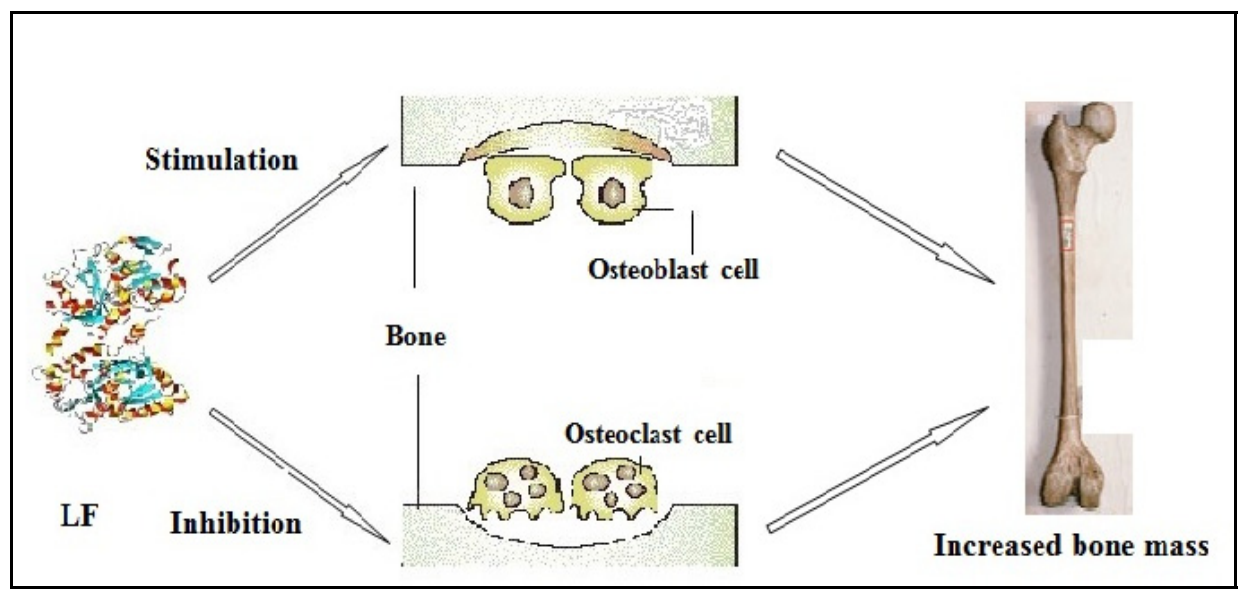

Figure 2. Lactoferrin has many mechanisms to build bone tissue.

\subsection{Lactoferrin as Immunomudolatory Agent}

The immunomodulatory activity is one of the very important activities of lactoferrin and this effect was reported on the immune system both in vivo and in vitro (Brock, 2002). Besides its direct effects in host defense on bacteria, fungus and parasites, it were reported possible roles in the modulation of the immune response and it activates the innate and acquired immunities. Lactoferrin may support the proliferation, differentiation, and activation of immune system cells cuasing strength the immune response (Legrand, Elass, Carpentier, \& Mazurier, 2005), and these effects may resulted by the association between lactoferrin's positive charge and the negatively charged molecules on the surface of various cells of the immune system (Baker, \& Baker, 2005). Also lactoferrin has the potency to enhance the expression of various types of cytokines in the intestinal mucosa such as IL-18, IFN- $\gamma$, IL-12, IFNs and IL-7 and these cytokines has a role in activation of immune cells (Yang, de la Rosa, Tewary, \& Oppenheim, 2009). As well as bovine lactoferrin supplements have the ability to support the immune system and influence immune cell activity (Mulder et al., 2008). The exogenous lactoferrin has the ability to transport as intact form from the intestine to the blood circulation through the enterocytes by endocytosis and this it was reported in vitro (Fisher et al., 2007) and in vivo (Hutchens et al., 1991) studies. The intact lactoferrin form can stimulate intestine-associated immune functions and thereby enhance the immunocompetence during the postnatal period (Kuhara, Yamauchi, Tamura, \& Okamura, 2006). Lactoferrin receptors play an important role in lactoferrin internalization but this mechanism still unclear (Jiang, Lopez, Kelleher, \& Lönnerdal, 2011).

Finally, it is known that using of naturally occurring ingredient and food bioactive components such as carotenoids, flavonoids, phenolic compounds, fiber and oligosaccharides have many therapeutic effects and recently lactoferrin is considered a prominent active protein.

Given the emerging knowledge of the biological importance of human lactoferrin in infant nutrition, the EFSA Journal (2012), regarded the notion of lactoferrin supplementation as worthy of consideration. However, clinical studies will be essential to demonstrate the efficacy and safety of such addition. With this background, it should be considered that lactoferrin has enough beneficial properties on human health to can be considered as a functional ingredient if it is added to some foods such as infant formulas.

\section{Lactoferrin as Ingredient of Infant Formulas}

Nutritional efficacy and safety are not the only challenge of the infant nutrition research and the infant formula development. When infants are bottle-fed should intake a food with similar properties to mother's milk for its optimal growth and development (Alles, Scholtens, \& Bindles, 2004). This fact, far to be easy to achieve, 
requires a deep knowledge of the human milk properties and to identify which are the responsible compounds of the beneficial effects on the health of infant's breastfed.

In general, infant formulas have been designed to provide infants with all the required nutrients, being an adequate nutritional formula. For that purpose, infants with an age of 0-6 months, it has estimated to be safe an intake of approximately $1.2 \mathrm{~g}$ bovine lactoferrin per day from infant formula containing $200 \mathrm{mg}$ bovine lactoferrin $/ 100 \mathrm{~g}$ (European Food Safety Authority, EFSA, 2012). However, research advances are focused on those substances in human milk, which serve other than traditional nutritional roles. Attempts are in progress to supplement infant formulas with protective and trophic factors so far unique only to human milk. The final aim is not necessarily to mimic the composition of human milk in every respect, but to achieve physiological effects as in breast fed infants (Gallego, Pérez-Conesa, Bernal Cava, Periago-Castón, \& Ros, 2009). Since human milk contains a considerable amount of lactoferrin, special attention is paid to its functional role. Many of those functions are directly related to its ability to bind iron, that is, its effect on iron absorption and bacteriostatic and antioxidant activities. Based on this, the addition of lactoferrin to infant formulas seems to be reasonable; nevertheless, the supplementation of infant formulas should be discussed intensively because there has to be a scientifically proven advantage for the infant to get this protein by daily formula (Sawatzki, 1997). Recently, EFSA (2012) accepted and approved bovine lactoferrin as a new food ingredient. Nowadays, there are many infant formulas supplemented with lactoferrin available in the market (Mulder, Connellan, Oliver, Morris, \& Stevenson, 2008). From results obtained by different authors, it can be concluded that the addition of lactoferrin, usually bovine, to infant formulas, does not affect iron absorption. However, given its ability to bind iron, its use in infant formulas could be useful for protecting the gut of infants against infections from microbial-requiring iron, its ability to reduce interelemental interactions and especially to protect infant formulas supplemented with iron and ascorbic acid against free radical formation.

In this context, Raiten, Talbot and Waters (1998) and Wakabayashi et al. (2006) reported that it is possible to enrich infant formulas with bovine or recombinant human lactoferrin, although the former does not seem to affect iron absorption, probably because of an incompatibility with the intestinal receptors, and in the latter, there is not enough available information to evaluate toxicity. In this regard, it must be taken into account that the enrichment of infant formulas with human lactoferrin would probably lead to an improvement in their amino acidic profile, making it more similar to that of human milk (Jovani, Barberá, \& Farré, 2001).

The EFSA (2012) considered that the bovine lactoferrin, is essentially protein constituent of cow milk and is considered a novel food ingredient. Bovine lactoferrin is present in the novel food ingredient mostly as non-denatured lactoferrin. It must be noted that lactoferrin is a normal constituent of human milk, and that the intended consumption of the bovine lactoferrin is within the levels of human lactoferrin consumed in breast milk by infants; human lactoferrin is also non-denatured.

Currently, bovine lactoferrin is added as a supplement to several products in Japan, including infant formula, yoghurt (Wakabayashi et al., 2006). Similarly, infant formulas enriched with bovine lactoferrin are also available in other countries, including Indonesia, South Korea and Spain (Conesa, Calvo, \& Sanchez, 2010).

\section{Conclusion}

The present review directs the attention towards some of the functional roles of lactoferrin and its roles in increasing the functional benefits of infant formulas. Lactoferrin is a new strategy for overcome some disease whether by orally administration or by food supplementation. Now is authorized and recommended using of lactoferrin as a new bioactive ingredient in the manufacturing of infant formulas to provide infants with nutritional and healthy effects especially for formula-fed infants and also after first 4-6 months. Many studies are required to study the effect of manufacturing and storage of infant formulas on lactoferrin. Also it is possible using lactoferrin-derived functionally peptides for enrichment the infant formulas and this may be one of the growing and promising field of research.

\section{Acknowledgements}

Esmat Aly was supported by a grant of the Spanish Ministry of Foreign Affairs and Cooperation-AECID ( $\mathrm{n}^{\circ}$ 0000595994).

\section{References}

Abiona, T. C., Onayade, A. A., Ijadunola, K. T., Obiajunwa, P. O., Aina O. I., \& Thairu, L. N. (2006). Acceptability, feasibility and affordability of infant feeding options for HIV-infected women: a qualitative study in south-west Nigeria. Maternal and Child Nutrition, 2, 135-144. http://dx.doi.org/10.1111/j.1740-8709.2006.00050.x 
Adlerova, L., Batroskova, A., \& Faldyna, M. (2008). Lactoferrin: a review. Veterinari Medicina, 53(9), 457-468.

Alles, M. S., Scholtens, P. A. S. M., \& Bindles, J. (2004). Current trends in the composition of infant milk formulas. Current Pediatric, 14 (1), 51-63. http://dx.doi.org/10.1016/j.cupe.2003.09.007

American Academy of Pediatrics. (2012). Breastfeeding and the Use of Human Milk. Pediatrics, 129, e827-e841. http://dx.doi.org/10.1542/peds.2011-3552

Artym, J., \& Zimecki, M. (2005). The role of lactoferrin in the proper development of newborns. Postepy Higieny i Medycyny Doświadczalnej, 59, 421-432.

Babina, S. E., Kanyshkova, T. G., Buneva, V. N., \& Nevinsky, G. A. (2004). Lactoferrin is the major deoxyribonuclease of human milk. Biochemistry (Moscow), 69(9), 1006-1015. http://dx.doi.org/10.1023/B:BIRY.0000043543.21217.b3

Baker, E. N., \& Baker, H. M. (2005). Lactoferrin molecular structure, binding properties and dynamics of lactoferrin. Cell Molecular and Life Science, 62, 2531-2539. http://dx.doi.org/10.1007/s00018-005-5368-9

Baró, L., Jiménez, J., Martinez-Férez, A., \& Boza, J. J. (2001). Bioactive compounds derived from human milk. Ars Pharmaceutica, 42(1), 21-38.

Baveye, S., Elass, E., Mazurier, J., Spik, G., \& Legrand, D. (1999). Lactoferrin: a multifunctional glycoprotein involved in the modulation of the inflammatory process. Clinical Chemistry and Laboratory Medicine, 37, 281-286. http://dx.doi.org/10.1515/CCLM.1999.049

Bellamy, M., Takase, H., Wakabayashi, K., Kawase, \& Tomita, M. (1992). Antibacterial spectrum of lactoferricin $\mathrm{B}$, a potent bactericidal peptide derived from the N-terminal region of bovine lactoferrin. Journal of Applied Bacteriology, 73(6), 472-479. http://dx.doi.org/10.1111/j.1365-2672.1992.tb05007.x

Blais, A., Malet, A., Mikogami, T., Martin-Rouas, C., \& Tomé, D. (2009). Oral bovine lactoferrin improves bone status in ovariectomized mice. The American Journal of Physiology-Endocrinology and Metabolism, 296, E1281-1288. http://dx.doi.org/10.1152/ajpendo.90938.2008.

Britton, J. R., \& Koldovsky, O. (1987). Luminal digestion of lactoferrin in suckling and weanling rats. The American Journal of Physiology, 253, G397-G403.

Brock, J. H. (2002). The physiology of lactoferrin. Biochemistry and Cell Biology, 80, 1-6. http://dx.doi.org/10.1139/o01-212

Cashman, K. D. (2002). Trace elements, Nutritional Significance. In U. Roginski, H. Fuquay \& J. W. Fox (Eds.), Encyclopedia of Dairy Sciences, 3, (pp. 2059-2065). London: Academic Press.

Chantry, C. J., Howard, C. R., \& Auinger, P. (2006). Full breastfeeding duration and associated decrease in respiratory tract infection in US children. Pediatrics, 117, 425-432. http://dx.doi.org/10.1542/peds.2004-2283

Chatterton, D. E. W., Rasmussen, J. T., Heegaard, C. W., Sorensen, E. S., \& Petersen, T. E. (2004). In vitro digestion of novel milk protein ingredients for use in infant formulas: Research on biological functions. Trends in Food Science Technology, 15, 373-383. http://dx.doi.org/10.1016/j.tifs.2003.12.004

Chierici, R., \& Vigi, V. (1994). Lactoferrin in infant formula. Acta Paediatrica, 402, 83-88. http://dx.doi.org/10.1111/j.1651-2227.1994.tb13367.x

Chirico, G., Marzoll, R., Cortinovis, S., Fonte, C., \& Gasparino, A. (2008). Anti-infective properties of human milk. Journal of Nutrition, 138, S1801-S1806. http://jn.nutrition.org/content/138/9/1801S.full.pdf

Conesa, C., Calvo, M., \& Sánchez, L. (2010). Recombinant human lactoferrin: A valuable protein for pharmaceutical products and functional foods. Biotechnology Advances, 28, 831-838. http://dx.doi.org/10.1016/j.biotechadv.2010.07.002

Coonely, O. M. (2001). Anti-inflammatory activities of lactoferrin. Journal of the American College of Nutrition, 2(5), 389S-395S.

Coppa, G. V., Zampini, L., Galeazzi, T., \& Gabrielli, O. (2006). Prebiotics in human milk: a review. Digestive Liver Disease, Amsterdam, 38(2), 291-294. http://dx.doi.org/10.1016/S1590-8658(07)60013-9

Cornish, J. (2004). Lactoferrin promotes bone growth. Biometals, 17, 331-335. http://dx.doi.org/10.1023/B:BIOM.0000027713.18694.91 
Cornish, J., \& Naot, D. (2010). Lactoferrin as an effector molecule in the skeleton. Biometals, 23, 425-430. http://dx.doi.org/10.1007/s10534-010-9320-6

Darshan, D., \& Anderson, G. J. (2007). Liver-gut axis in the regulation of iron homeostasis. World Journal of Gastroenterology, 13, 4737-4745.

Davidson, L. A., \& Lonnerdal, B. (1987). Persistence of human milk proteins in the breast-fed infant. Acta Paediatrica Scandinavica, 76, 733-740. http://dx.doi.org/10.1111/j.1651-2227.1987.tb10557.x

Domellof, M., Lonnerdal, B., Abrams, S. A., \& Hernell, O. (2002). Iron absorption in breast-fed infants: effects of age, iron status, iron supplements, and complementary foods. The American Journal of Clinical Nutrition, 76, 198-204. http://ajcn.nutrition.org/content/76/1/198.full

Drago, S. M. E. (2006). Actividades antibacterianas de la lactoferrina. Enfermedades Infecciosas y Microbiología, 26, 58-63. http://www.amimc.org.mx/revista/2006/26-2/actividades.pdf

Ella, E. E., Ahmed, A. A., Umoh, V. J., Ogala, W. N., \& Balogun, T. B. (2009). Lactoferrin levels in human breast milk among lactating mothers with sick and healthy babies in Kaduna state, Nigeria. International Journal of Medicine and Medical Science, 1(11), 495-500.

European Food Safety Authority (EFSA) Panel on Dietetic Products Nutrition and Allergies. (2012). Scientific opinion on bovine lactoferrin. EFSA Journal, 10, 1-26.

Fairweather-Tait, S. J., Wright, A. G. A., \& Piper, Z. (1986). The influence of human and bovine lactoferrin on iron absorption from ferrous sulphate in rats. Proceedings of the Nutrition Society. 45, 40A.

Farnaud, S., \& Evans, R. W. (2003). Lactoferrin: a multifunctional protein with antimicrobial properties. Molecular Immunology, 40, 395-405. http://dx.doi.org/10.1016/S0161-5890(03)00152-4.http://dx.doi.org/

Fischer, R., Debbabi, H., Blais, A., Dubarry, M., Rautureau, M., Boyaka, P. N., \& Tome, D. (2007). Uptake of ingested bovine lactoferrin and its accumulation in adult mouse tissues. International Immunopharmacology, 7(10), 1387-1393. http://dx.doi.org/10.1016/j.intimp.2007.05.019

Fujita, K., Matsuda, E., Sekine, K., ligo, M., \& Tsuda, H. (2004). Lactoferrin enhances Fas expression and apoptosis in the colon mucosa of azoxymethane-treated rats. Carcinogenesis, 25, 1961-1966. http://dx.doi.org/10.1093/carcin/bgh205

Garcia-Montoya, I. A., Cendon, T. S., Arevalo-Gallegos, S., \& Rascon-Cruz, Q. (2012). Lactoferrin a multiple bioactive protein: an overview. Biochemica et Biophysica Acta, 1820(3), 226-236. http://dx.doi.org/10.1016/j.bbagen.2011.06.018

Giuffre', G., Barresi, V., Skliros, C., Barresi, G., \& Tuccari, G. (2007). Immuno-expression of lactoferrin in human sporadic renal cell carcinomas. Oncology Reports, 17, 1021-1026.

Gonzalez-Chavez, S., Arevalo-Gallegos, S., \& Rascon-Cruz, Q. (2009). Lactoferrin: structure, function and applications. International Journal of Antimicrobial Agents, 33, 301. e1-301. e8. http://dx.doi.org/10.1016/j.jjantimicag.2008.07.020

Gomez Gallego, G. C., Pérez-Conesa, D., Bernal Cava, M. J., Periago-Castón, M. J., \& Ros, G. (2009). Functional compounds in breast milk. Revista electrónica cuatrimestral de enfermería Global,. 8(16), 1-14. http://dx.doi.org/10.4321/S1695-61412009000200020

Hallberg, L., Brune, M., \& Rossander, L. (1989). Iron absorption in man: ascorbic acid and dose-dependent inhibition by phytate. American Journal of Clinical Nutrition, 49, 140-144.

Harvard, J., \& Hancock, R. E. W. (2009). Antimicrobial properties of lactoferrin. Biochimie, 91, 19-29. http://dx.doi.org/10.1016/j.biochi.2008.05.015

Hayashida, K., Kaneko, T., Takeuchi, T., Shimizu, H., Ando, K., \& Harada, E. (2004). Oral administration of lactoferrin inhibits inflammation and nociception in rat adjuvant-induced arthritis. The Journal of Veterinary Medical Science, 66, 149-154.

Heaney, R. P., Abrams, S., Dawson-Hughes, B., Looker, A., Marcus, R. Matkovic, V., \& Weaver, C. (2000). Peak bone mass. Osteoporosis International, 11(12), 985-1009. http://dx.doi.org/10.1007/s00198-012-2232-2

Hutchens, T. W., Henry, J. F., Yip, T. T., Hachey, D. L., Schanler, R. J., Motil, K. J., \& Garza, C. (1991). Origin of intact lactoferrin and its DNA-binding fragments found in the urine of human milk-fed preterm 
infants. Evaluation by stable isotopic enrichment. Pediatric Research, 29(3), 243-250. http://dx.doi.org/10.1203/00006450-199103000-00005

Iigo, M., Alexander, N., Long, J., Xu, K., Fukamachi, M., Futakuchi, Takase, M., \& Tsuda, H. (2009). Anticarcinogenesis pathways activated by bovine lactoferrin in the murine small intestine. Biochemie, 91(1), 86-101. http://dx.doi.org/10.1016/j.biochi.2008.06.012

Jameson, G. B., Anderson, B. F., Norriss, G. E., Thomas, D. H., \& Baker, E. N. (1998). Structure of human apolctoferrin at 2.0 a resolution. Refinement and analysis of ligand-induced conformational change. Acta Crystallographica, D54, 1319-1335. http://dx.doi.org/10.1107/S0907444998004417

Jiang, R., Lopez, V., Kelleher, S. L., \& Lönnerdal, B. (2011). Apo- and holo-lactoferrin are both internalized by lactoferrin receptor via clathrin-mediated endocytosis but differentially affect ERK-signaling and cell proliferation in Caco-2 cells. Journal of Cellular Physiology, 226(11), 3022-3031. http://dx.doi.org/10.1002/jcp.22650

Jovani, M., Barbera, R., \& Farré, R. (2001). Lactoferrin and its possible role in iron enrichment of infant formulas. Food Science and Technology International, 7(2), 97-103. http://dx.doi.org/10.1177/108201320100700201

Kaim, W., \& Schwedereski, B. (1994). Transport and storage of iron. In John Wiley \& Sons (Eds.), Bioinorganic Chemistry: Inorganic Elements in the Chemistry of Life (pp. 162-165). England: Bookcraft (Bath) Ltd., Midsomer Norton, Somerset.

Kang, J. H., Lee, M. K., Kim, K. L., \& Hahm, K. S. (1996). Structure biological activity relationships of 11-residue highly basic peptide segment of bovine lactoferrin. International Journal of Peptide and Protein Research, 48(4), 357-363. http://dx.doi.org/10.1111/j.1399-3011.1996.tb00852.x

Kanyshkova, T. G., Buneva, V. N., \& Nevinsky, G. A. (2001). Lactotrferrin and its biological functions. Biochemistry (Moscow), 66(1), 1-7. http://dx.doi.org/10.1023/A:1002817226110

Kim, W. S., Ohashi, M., Tanaka, T., Kumura, H., Kim, G. Y., Kwon, I. K., ... Shimazaki, K. (2004). Growth-promoting effects of lactoferrin on L. acidophilus and Bifidobacterium spp. Biometals (Oxford), 17(3), 279-283. http://dx.doi.org/10.1023/B:BIOM.0000027705.57430.f1

Kim, W. S., Rahman, M. M., kumura, H., \& Shimazaki, K. (2005). Comparison of growth promoting effects on bifidobacteria spp. by bovine lactoferrin hydrolysates. Bioscience Microflora, 24(4), 119-123.

Kramer, M. S., \& Kakuma, R. (2002). Optimal duration of exclusive breastfeeding. Cochrane Database Systematic Review, 1, 1-106. http://dx.doi.org/10.1002/14651858.CD003517

Kuhara, T., Yamauchi, K., Tamura, Y., \& Okamura, H. (2006). Oral administration of lactoferrin increases NK cell activity in mice via increased production of IL-18 and type I IFN in the small intestine. Journal of Interferon Cytokine Research, 26(7), 489-499. http://dx.doi.org/10.1089/jir.2006.26.489

Kuwata, H., Yamauchi, K., Teraguchi, S., Ushida, Y., Shimokawa, Y., Toida, T., \& Hayasawa, H. (2001). Functional fragments of ingested lactoferrin are resistant to proteolytic degradation in the gastrointestinal tract of adult rats. The Journal of Nutrition, 131(8), 2121-2127. http://jn.nutrition.org/content/131/8/2121.full.pdf

Legrand, D., Elass, E., Carpentier, M., \& Mazurier, J., (2005). Lactoferrin: a modulator of immune and inflammatory responses. Cell Molecular and Life Science, 62(22), 2549-2559. http://dx.doi.org/10.1007/s00018-005-5370-2

Lizzi, A. R., Carnicelli, V., Clarkson, M. M., Di Giulio, A., \& Oratore, A. (2009). Lactoferrin derived peptides: mechanisms of action and their perspectives as antimicrobial and antitumoral agents. Mini-Reviews in Medicinal Chemistry, 9(6), 687-695. http://dx.doi.org/10.2174/138955709788452757

Lonnerdal, B. (1989). Dietary factors affecting trace elements absorption in infants. Acta paediatrica scandinavica, S351, 109-113. http://dx.doi.org/10.1111/j.1651-2227.1989.tb11220.x

Lonnerdal, B., \& Iyer, S. (1995). Lactoferrin: molecular structure and biological function. Annual Review of Nutrition, 15, 93-110. http://dx.doi.org/10.1146/annurev.nu.15.070195.000521

Lorget, F., Clough, J., Oliveira, M., Daury, M. C., Sabokbar, A., \& Offord, E. (2002). Lactoferrin reduces in vitro osteoclast differentiation and resorbing activity. Biochemical and Biophysical Research Communications, 296, 261-266. http://dx.doi.org/10.1016/S0006-291X(02)00849-5 
Losnedahl, K. J., Wang, H., Aslam, M., Zou, S., \& Hurley, W. L. (1998). Antimicrobial Factors in Milk. Illini Dairy Net Papers, University of Illinois.

Makino, Y., \& Nishimura, S. (1992). High performance liquid chromatographic separation of human apolactoferrin and monoferric and diferric lactoferrin. Journal of Chromatography, 579, 346-349. http://dx.doi.org/10.1016/0378-4347(92)80402-C

Mathew, J. L. (2004). Effect of maternal antibiotics on breast feeding infants. Postgraduate Medical Journal, 80, 196-200. http://dx.doi.org/10.1136/pgmj.2003.011973

Matsuda, Y., Saoo, K., Hosokawa, K., Yamakawa, K., Yokohira, M., Zeng, Y., ... Imaida, K. (2006). Post-initiation chemo-preventive effects of dietary bovine lactoferrin on 4-(methylnitrosamino)-1-(3-pyridyl)-1-butanone-induced lung tumorigenesis in female $\mathrm{A} / \mathrm{J}$ mice. Cancer Letters, 246, 41-46. http://dx.doi.org/10.1016/j.canlet.2006.01.034

Mulder, A. M., Connellan, P. A., Oliver, C. J., Morris, C. A., \& Stevenson, L. M. (2008). Bovine lactoferrin supplementation supports immune and antioxidant status in healthy human males. Nutrition Research, 28, 583-589. http://dx.doi.org/10.1016/j.nutres.2008.05.007

Mundy, G. R. (1999). Bone remodeling. In M. J. Favus (Ed.), Primer on the Metabolic Bone Disease and Disorders of Mineral Metabolism (pp. 30-38). (Fourth edition). Philadelphia, Lippincot Williams \& Welkins.

Naot, D., Grey, A., Reid, L. R., \& Cornish, J. (2005). Lactoferrin: a novel bone growth factor. Clinical Medicine \& Research, 3(2), 93-101. http://dx.doi.org/10.3121/cmr.3.2.93

Newburg, D. S. (2000). Oligosaccharides in human milk and bacterial colonization. Journal of Pediatric and Gastroenterology Nutrition, 30, S8-S17. http://dx.doi.org/10.1097/00005176-200003002-00003

Norrby, K., Mattsby-Baltzer, I., Innocenti, M., \& Tuneberg, S. (2001). Orally administered bovine lactoferrin systemically inhibits VEGF (165)-mediated angiogenesis in the rats. International Journal of Cancer, 91, 236-240. http://dx.doi.org/10.1002/1097-0215(200002)

Pan, Y., Rowney, M., Guo, P., \& Hobman, P. (2007). Biological properties of lactoferrin: an overview. Australian Journal of Dairy Technology, 62(1), 31-42.

Petit, A. I. (2008). Perception and knowledge on exclusive breastfeeding among women attending antenatal and postnatal clinics. A study from Mbarara Hospital, Uganda (pp. 27-30). Tanzania Medical Students' Association.

Raiten, D. J., Talbot, J. M., \& Waters, J., H. (1998). Assessment of nutrient requirement for infant formulas. The Journal of Nutrition, 128(11S), 2059S-2294S.

Redel, C. A., \& Shulman, R. J. (1994). Controversies in the composition of infant formulas. Pediatric Clinics of North America, 41, 909-923.

Renner, E., Scchaafsma, G., \& Scott, K. J. (1989). Micronutrients in milk. In E. Renner (Ed.), Micronutrients in milk and milk-based products. (pp. 1-60). New Yourk: Elsevier Applied Science.

Sacrino, M. L. (2007). A sideways glance: Take it or leave it? The role of lactoferrin in iron sequestration and delivery within the body. Genes Nutrition, 2, 161-162. http://dx.doi.org/10.1007/s12263-007-0054-1

Sanchez, L., Calvo, M., \& Brock, J. H. (1992). Biological role of lactoferrin. Archives of disease in childhood, 67, 657- 661. http://dx.doi.org/10.1136/adc.67.5.657

Sawatzki, G. (1997). Lactoferrin in infant formulas. Experimental Biology and Medicine, 28, 389-397.

Sharp, P., \& Srai, S. K. (2007). Molecular mechanisms involved in intestinal iron absorption. World Journal of Gastroenterology, 21(35), 4716-4724. http://www.wjgnet.com/1007-9327/13/4716.asp

Sigel, A., \& Sigel, H. (1988). Transferrin, the transferring receptor, and the uptake of iron by cells. In A. Y. Sigel \& H. Sigel (Eds.), Metal ions in Biological Systems (Vol. 35, pp. 586-631). New York: Marcel Dekker.

Sinha, M., Kaushik, S., Kaur, P., Sharma, S., \& Singh, T. P. (2013). Antimicrobial Lactoferrin Peptides: The Hidden Players in the Protective Function of a Multifunctional Protein. International Journal of Peptides, 3, 1-12. http://dx.doi.org/10.1155/2013/390230

Steijns, J. M., \& van Hooijdonk, C. M. (2000). Occurrence, structure, biochemical properties and technological characteristics of lactoferrin. British Journal of Nutrition, 84(1), S11-S17. http://dx.doi.org/10.1017/S0007114500002191 
Story, L., \& Parish, T. (2008). Breastfeeding helps prevent two major infant illnesses. The Internet Journal of Allied Health Science and Practice, 6(3), 1-5. http://ijahsp.nova.edu/articles/vol6num3/pdf/story.pdf

Stransky, M., \& Rysava, L. (2009). Nutrition as prevention and treatment of osteoporosis. Physiological Research, 1, S7-S11. http://www.biomed.cas.cz/physiolres/pdf/58\%20Suppl\%201/58_S7.pdf

Stowell, K. M., Rado, T. A., Funk, W. D., \& Tweedie, J. W. (1991). Expression of cloned human lactoferrin in baby hamster kidney cells. Journal of Biochemistry, 276, 349-355.

Suzuki, Y. A, Shin, K., \& Lonnerdal, B. (2001). Molecular cloning and functional expression of a human intestinal lactoferrin receptor. Biochemistry, 40, 15771-15779. http://dx.doi.org/10.1021/bi0155899

Svoboda, M., Drábek, J., \& Ficek, R. (2005). Effect of bovine lactoferrin on utilization of orally administered iron in suckling piglets. Bulletin of the veterinary institute in pulawy, 49, 471-474.

Tsuda, H., Sekine, K., Fujita, K., \& Ligo, M. (2002). Cancer prevention by bovine lactoferrin and underlying mechanism-a review of experimental and clinical studies. Biochemistry and Cell Biology, 80, 131-136. http://dx.doi.org/10.1139/o01-239

Tsuda, H., Kozu, T., Iinuma, G., Ohashi, Y., Saito, Y., Saito, D., ... Iigo, M. (2010). Cancer prevention by bovine lactoferrin: from animal studies to human trial. Biometals, 23, 399-409. http://dx.doi.org/10.1007/s10534-010-9331-3

Vorland, L. H. (1999). Lactoferrin: a multifunctional glycoprotein. Acta pathologica, Microbiologica et Immunologica Scandinavica (APMIS), 107, 971-981. http://dx.doi.org/10.1111/j.1699-0463.1999.tb01499.x

Wakabayashi, H., Yamauchi, K., \& Takase, M. (2006). Lactoferrin research, technology and applications. International Dairy Journal, 16, 1241-1251. http://dx.doi.org/10.1016/j.idairyj.2006.06.013

Walkar, A. (2010). Breast milk as the gold standard for protective nutrients. Journal of Pediatrics, 156(2), S3-S7. http://dx.doi.org/10.1016/j.jpeds.2009.11.021

Wang, W. P., Iigo, M., Sato, J., Sekine, K., Adachi, I., \& Tsuda H. (2000). Activation of intestinal mucosal immunity in tumor-bearing mice by lactoferrin. Japan Journal of Cancer Research, 91, 1022-1027. http://dx.doi.org/10.1111/j.1349-7006.2000.tb00880.x

Wang, X. Y., Guo, H. Y., Zhang, W., Wen, P. C., Zhang, H., Guo, Z. R., \& Ren, F. Z. (2013). Effect of iron saturation level of lactoferrin on osteogenic activity in vitro and in vivo. Journal of Dairy Science, 96(1), 33-39. http://dx.doi.org/10.3168/jds.2012-5692

Ward, P. P., Mendoza-Meneses, M., Cunningham, G. A., \& Conneely, O. M. (2003). Iron status in mice carrying a targeted disruption of lactoferrin. Molecular and cellular biology, 178-185. http://dx.doi.org/10.1128/MCB.23.1.178-185.2003

Whiting, S. J., Vatanparast, H., Baxter-Jones, A., Faulkner, R. A., Mirwald, R., \& Bailey, D. A. (2004). Factors that affect bone mineral accrual in the adolescent growth spurt. Journal of Nutrition, 134(3S), 696S-700S. http://jn.nutrition.org/cgi/content/abstract/134/3S/696S

Yang, D., de la Rosa, G., Tewary, P., \& Oppenheim, J. J. (2009). Alarmins link neutrophils and dendritic cells. Trends in Immunology, 30(11), 531-537. http://dx.doi.org/10.1016/j.it.2009.07.004

Yu, R. H., \& Schryvers, A. B. (2002). Bacterial lactoferrin receptors: insight from characterizing the Moraxella bovis receptors. Biochemistry and Cell Biology, 80, 81-90. http://dx.doi.org/10.1139/o01-235

Zivkovic, A. M., German, J. B., Lebrilla, C. B., \& Mills, D. A. (2011). Human milk glycobiome and its impact on the gastrointestinal microbiota. Proceedings of the National Academy of Science of USA, 108(1), 4653-4658. http://dx.doi.org/10.1073/pnas.1000083107

\section{Copyrights}

Copyright for this article is retained by the author(s), with first publication rights granted to the journal.

This is an open-access article distributed under the terms and conditions of the Creative Commons Attribution license (http://creativecommons.org/licenses/by/3.0/). 